\title{
A New Dammarane Triterpenoid Compound Isolated From Ixora Finlaysoniana
}

\author{
*Magda T. Ibrahim ${ }^{1}$, Khaled Meselhy ${ }^{2}$, Asmaa I. Ali $^{3}$, Amany A. Sleem ${ }^{4}$

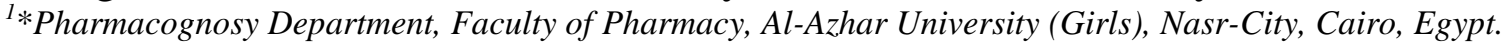 \\ ${ }^{2}$ Pharmacognosy Department, Faculty of Pharmacy, Cairo University, Cairo, Egypt. \\ ${ }^{3}$ Pharmacognosy Department, Faculty of Pharmacy, Misr International University, Cairo, Egypt. \\ ${ }^{4}$ Department of Pharmacology, National Research Centre, Giza, Egypt.
}

\begin{abstract}
The air-dried leaves of Ixora finlaysoniana Wall. ex. Don (family Rubiaceae) afforded a new dammarane triterpenoid named: $17 \beta$-dammara-1-one -20 ene-3 $\beta$-3', 8'-dimethyloctanoate (1) together with two known saturated fatty acids capric (2) and palmitic (3) from the chloroform extract as well as three phenolic acids: gallic (4), caffeic (5), chlorogenic (6), six flavonols: Kaempferol 3-O- $\beta$-D-arabinopyranoside (7), afzelin (8), Kaempferol-3-O- $\beta$-glucopyranosyl-7-O-glucuropyranoside(9), Kaempferol-3-O- $\alpha$ - $L$ rhamnopyranosyl $\quad\left(1^{\prime \prime \prime} \rightarrow 6^{\prime \prime}\right)\left(4^{\prime \prime}\right.$-trans-p-coumaroyl) $\beta$-D-glucopyranoside-7-O- $\alpha$-L-rhamnopyranoside $\quad(10)$, Kaempferol-3-O- $\alpha$-L-rhamnopyranosyl $\left(1^{\prime \prime \prime} \rightarrow 2^{\prime \prime}\right)\left(4^{\prime \prime}\right.$-trans-p-coumaroyl) $\beta$-D-arabinopyranosid-7-O- $\alpha$ - $L$ -

rhamnopyranoside (11) and kaempferol (12) in addition to two isoflavones: Biochanin A (13), Biochanin A-7$O$ - $\beta$-D-rutinoside (14) were isolated from methanol extract. All these structures were isolated for the first time from Ixora finlaysoniana leaves and were elucidated by different chromatographic and $U V$, extensive $1 D$ and $2 D N M R$ spectroscopy and $M S$.
\end{abstract}

Keywords: Ixora finlaysoniana, Rubiaceae, dammarane triterpenoid, kaempferol derivatives, isoflavones

\section{Introduction}

Medicinal plants have been of long age remedies for human diseases because they contain components of therapeutic value and used in modern medicine where they occupy a very significant place as raw material for economically important drugs ${ }^{[1]}$. Ixora is a genus of flowering plants (family Rubiaceae ) of Asian origin and was introduced into Egypt as an ornamental. The plant is traditionally found to be useful for many ailments like hepatic disorder, cancer, microbial infection, antioxidant, pain, inflammation and has been documented for various medicinal properties. Red Ixora is the most popular one commonly used in Indian folk medicine and it is known as Ixora coccinea ${ }^{[2]}$. Ixora finlaysoniana Wall.ex.G.Don. is a handsome woody shrub with showy flowers in clusters and evergreen foliage. The dried entire plant of Ixora finlaysoniana is used in Thailand as a strength medicine, while the ethanol extract of the plant was proved to have estrogenic effect. Reviewing the current literature for the chemical composition of Ixora finlaysoniana recovered only the isolation of apigenin4-O- $\beta$-D-glucopyranoside and 11-hydroxy-dodec-5-en-2-one. The botanical study of the stem and leaf of Ixora finlaysoniana cultivated in Egypt was previously carried out ${ }^{[3]}$. Although there are several reported studies on Ixora species, little was carried out on Ixora finlaysoniana Wall. ex G. Don., (Rubiaceae) relative to other species. Therefore, it was deemed of interest to continue our work ${ }^{[4]}$ for isolation the phytoconstituents from biologically active extracts.

\subsection{Plant material}

\section{Materials And Equipments}

The fresh leaves of Ixora finlaysoniana Wall. ex. G. Don. were collected from plants cultivated in the El-Zohria Botanical Garden, Giza, Egypt, during the spring (2011). The identity of the plant was kindly confirmed by Dr. Mohamed El Gebaly, Lecturer of Taxonomy and Prof. Dr. Wafaa M. Amer, Department of Botany, Faculty of Science, Cairo University for whom the authors are thankful. The leaves were air-dried and kept in tightly closed container while the flowers were used immediately for preparing the essential oil from it. Voucher specimens [IF-1] are kept in the Department of Pharmacognosy, Faculty of Pharmacy, Al-Azhar University until extraction process.

\subsection{General equipments and chemicals}

NMR analyses were measured on Bruker Avance III operating at $\left(400 \mathrm{MHz}\right.$ for ${ }^{1} \mathrm{H}$ and $100 \mathrm{MHz}$ for ${ }^{13} \mathrm{C}$ ) (Bruker AG, Switzerland) with BBFO Smart Probe and Bruker 400 AEON Nitrogen-Free Magnet. Data were analyzed using Topspin 3.1 Software. All samples have been prepared in DMSO- $\mathrm{d}_{6}$ with TMS as internal reference, with the chemical shifts expressed in $\delta$ and coupling constants $(J)$ in Hertz. 
Electrospray (ESI)-MS was carried out using Thermo Finnigan LCQ Advantage MAX (ion trap) instrument (Finnigan, Bremen, Germany). Samples dissolved in $10 \mu 1$ of 50\% methanol. EI Mass spectrometer: (Chro $\mathrm{N}_{29} \mathrm{M}_{\mathrm{y}}$ 5526) Ver.1 on UIC 22. UV Spectrophotometer Shimadzu UV 240 (P/N 240-58000) used for recording different UV spectra. UV spectra of pure samples were recorded, separately, in $\mathrm{MeOH}$ using different diagnostic UV shift reagents in case of flavonoid ${ }^{[5]}$. For column chromatography (CC), for isolation of phenolic compounds was carried out on Polyamide 6S (Riedel-De-Haen AG, Seelze Haen AG, D-30926 Seelze Hanver, Germany) and Sephadex LH-20 (Pharmazia), Uppsala, Sweden), silica gel (Sigma, 28-200 mesh) was used for terpenoids CC, and F254 for TLC (Merck, Germany). Plates were visualized by spraying with EtOH/ $\mathrm{H}_{2} \mathrm{SO}_{4}$ and heating at $120^{\circ} \mathrm{C}$. PC (descending) Whatman No. 1 and $3 \mathrm{MM}$ papers phenolic and sugar, using solvent systems 15\% HOAc $\left(\mathrm{H}_{2} \mathrm{O}-\mathrm{HOAc}\right.$ 85:15), BAW (n-BuOH: HOAc: $\mathrm{H}_{2} \mathrm{O}$ 4:1:5, upper layer). Complete acid hydrolysis for $O$-glycosides was carried out \& followed by $\mathrm{CO}$-chromatograph with authentic samples to identify the aglycone and sugar moieties.

\subsection{Extraction and isolation}

\section{Methods}

The methodology of the extraction and isolation of Ixora finlaysoniana Wall. Ex. G. Don. leaves was summarized in Fig. (1). Identification of the structures of the isolated compounds was carried out using the chemical and physical methods of analysis as well as spectroscopic analysis such as UV, IR, MS, ${ }^{1} \mathrm{H}-\mathrm{NMR}$, ${ }^{13} \mathrm{C}-$ NMR and 2D NMR.

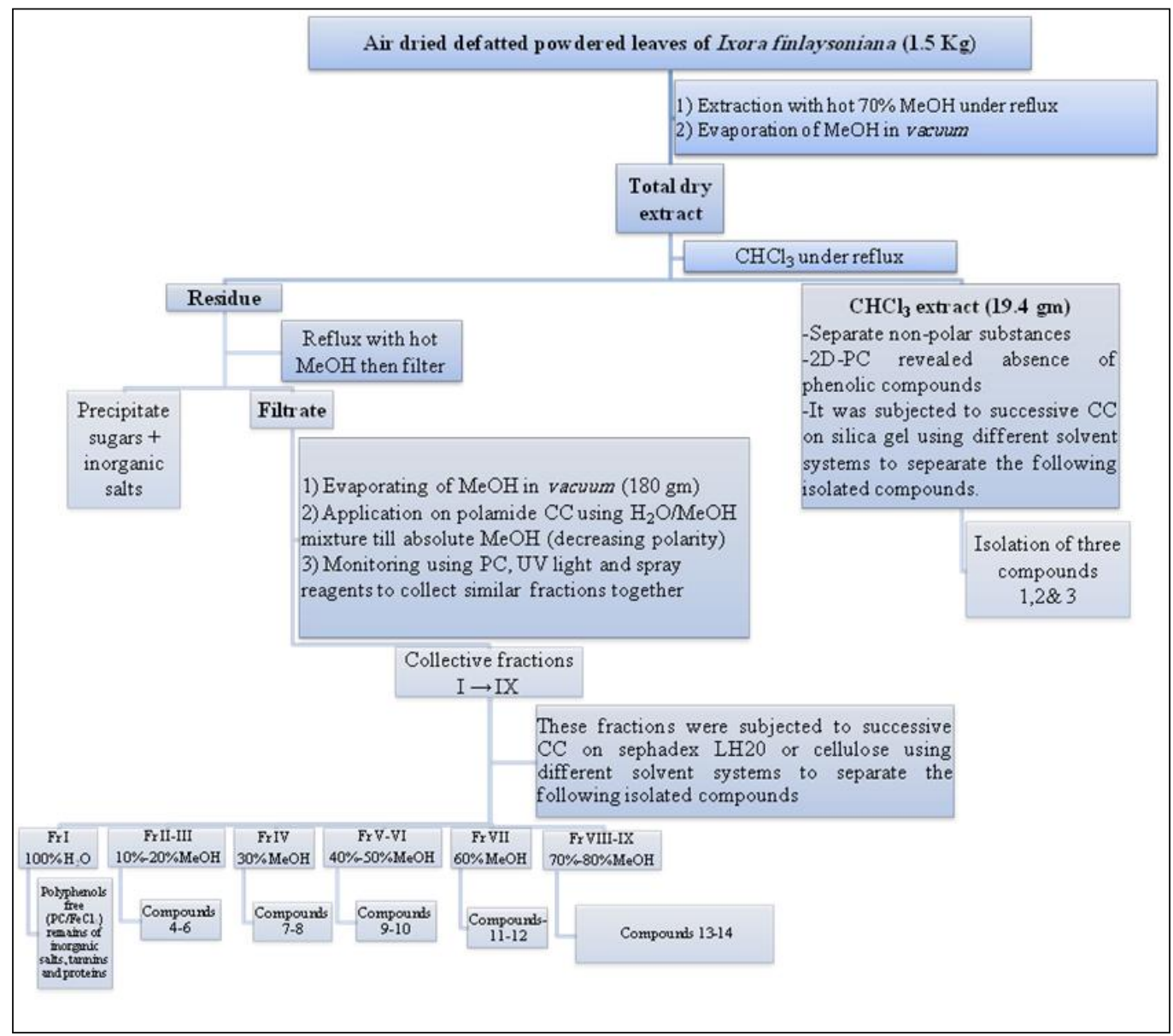

Flgure (1): The methodology of the extraction, isolation and purification of Ixora finlaysoniana Wall. ex.

\section{G. Don. Leaves}

\subsection{Biological studies}

\subsubsection{Preparation of plants extracts:}

The biological evaluation as a continuation of our work ${ }^{[4]}$ was performed on different extracts of Ixora finlaysoniana Wall. ex. G. Don. leaves (alcohol extract, petroleum ether fraction, chloroform fraction, ethyl acetate fraction, butanol fraction of leaves) and aqueous decoction as taken in folk medicine was obtained by boiling $(100 \mathrm{gm})$ of the powdered aerial parts of Ixora finlaysoniana in $200 \mathrm{ml}$ distilled water. Water was 
evaporated under vaccum to give $5.4 \mathrm{gm}$ residue. A solution of extract (in bi-distilled water) containing few drops of Tween 80 was prepared in different dilutions. For the pharmacological activity, 2.5 gm was taken from each fraction. All fractions were dissolved in $1 \%$ aqueous Tween 80.

\subsubsection{Experimental animals}

Adult male and female albino rats (25-30 g), in addition to male albino rats of Sprague Dawely Strain $(130-150 \mathrm{~g})$ were used. Animals were obtained from the animal house, of the National Research Center, Dokki, Giza, Egypt. The animals were fed on standard laboratory diet composed of vitamin mix (1\%), mineral mix (4 $\%)$, corn oil $(10 \%)$, sucrose $(20 \%)$, cellulose $(0.2 \%)$, casein $(10.5 \%)$ and starch $(54.3 \%)$.

\subsubsection{Reference drugs and kits}

Indomethacin (Epico, Egyptian Int. Pharmaceutical Industries Co) for anti-ulcer activity, Carbamazepin (Novartis Pharma, S.A.E., Egypt; under license of CIBA-GEIGY limited, Basle, Switerland) for anticonvulsant activity, Cidophage (CID Co., Egypt) Glutathione Kit (Wak, company-Germany) for antioxidant activity, Bio-Merieux kit for hypoglycemic activity, carbon tetrachloride (analar), Transaminase kits (BioMerieux Co.) for

hepatoprotective activity, Alloxan (Sigma Co.), and Vitamin E (Pharco Pharmaceutical Co. Egypt) inform of soft gelatin capsule, were used in the biological screening.

\subsection{Biological Experiments}

\subsubsection{Toxicity study:}

The $\mathrm{LD}_{50}$ of both alcohol extract of the leaves and aqueous extracts of the aerial parts of Ixora finlaysonianawas determined according to Karber, $1931^{[6]}$ procedure

\subsubsection{Anti-ulcer activity}

Acute ulcerogenic activity or gastric mucosa eroding of tested extracts was evaluated and compared with that of indomethacin as a standard using the method described by Corell et al., 1979 ${ }^{[7]}$.

\subsubsection{Anticonvulsant activity}

The anticonvulsant activity of tested extracts was evaluated and compared with that of carbamazepinas a standard, as described by Alberto et al., $1982^{[8]}$.

\subsubsection{Antioxidant activity}

The antioxidant activity of the tested samples of Ixora finlaysoniana was calculated by the determination of glutathione in blood of alloxan - induced diabetic rats adopting the method of Beutler et al., $1963{ }^{[9]}$. and using Vitamin $\mathrm{E}$ as a positive control

\subsubsection{Chronic hypoglycemic activity}

The tested samples were evaluated and compared by adopting the method described by Trinder method [10] and using Metformin (150 mg / kg b.wt.) as standard. Glucose levels were measured in blood samples collected at zero time $\left(\mathrm{G}_{0}\right)$ i.e. prior treatment and after 4 and $6 \mathrm{hrs}$ intervals from dose administration in case of treated animals $\left(\mathrm{G}_{\mathrm{t}}\right)$. The percentage change in blood glucose level from initial glycaemia was, in each case, calculated according to the following equation: $\%$ of change $=\left(\mathrm{G}_{0}-\mathrm{G}_{\mathrm{t}}\right) \times 100 / \mathrm{G}_{0}$

\subsubsection{Hepatoprotective activity}

The tested samples were evaluated by measuring serum AST, ALT ${ }^{[1]}$ and serum ALP ${ }^{[12]}$ using Silymarin $(25 \mathrm{mg} / \mathrm{Kg}$ b. wt.) as a standard. Male albino rats of Sprague Dawely Strain $(130-150 \mathrm{~g})$ were injected (i.p.) with $25 \%$ Carbon tetrachloride in liquid paraffin $\left(5 \mathrm{ml} / \mathrm{Kg}\right.$ b.wt.) to induce liver damage ${ }^{[13]}$. After oral administration of the tested samples and standard; serum ALT, AST and ALP were collected and the percentages of change in function of liver were calculated after 72 hours of administrating carbon tetrachloride and after 1 month. Serum ALT, AST and ALP were measured according to the method of Thewfweld, $1974^{[11]}$ and serum ALP according to method ${ }^{[12]}$ at zero time $\left(\mathrm{L}_{0}\right)$ and after treatment $\left(\mathrm{L}_{\mathrm{t}}\right)$. The percentage of change in function of liver was calculated according to the following equation: $\%$ of change $=\left(\mathrm{L}_{0}-\mathrm{L}_{\mathrm{t}}\right) \times 100 / \mathrm{L}_{0}$.

\subsection{Statistical analysis}

Results are expressed as mean \pm S.E., the significance of difference between test and control groups was established by the paired student's t test ${ }^{[14]} \mathrm{P}$ values of 0.05 or less were considered as criteria for significance.

\section{Experimental Data Of Isolated New Compound}

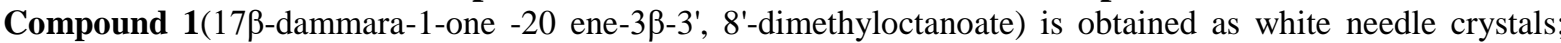
$\left(74.7 \mathrm{mg}\right.$ ) gave positive Libermman test, pink color after spraying with $\mathrm{EtOH} / \mathrm{H}_{2} \mathrm{SO}_{4}$ reagent indicating terpenoid nature. NMR spectroscopic data for new compound (300 $\mathrm{MHz}$ for ${ }^{1} \mathrm{H}$ and $100 \mathrm{MHz}$ for ${ }^{13} \mathrm{C}, \mathrm{CDCl}_{3}$ ) summarized in Table 1.

\section{Result And Discussion}

The chloroform extract of air-dried Ixora finlaysoniana Wall. ex. Don leaves ( family Rubiaceae) afforded a new dammarane triterpenoid obtained as white needle crystals; $(74.7 \mathrm{mg}$ ) gave positive Liebermann-Burchard test, pink color after spraying with EtOH/ $\mathrm{H}_{2} \mathrm{SO}_{4}$ reagent indicating terpenoid nature. 
IR spectrum revealed the presence of $\mathrm{C}=\mathrm{O}$ of ester at $1715 \mathrm{~cm}^{-1} \mathrm{CH}$ stretching at $2927 \mathrm{~cm}^{-1}$ and $2857,>\mathrm{C}=\mathrm{C}<$ at $1675 \mathrm{~cm}^{-1}$ with geminal methyls at $1380 \mathrm{~cm}^{-1[13]}$; whereas the terminal methylene showed vibration at 915 $\mathrm{cm}^{-1}$ in $\mathrm{CDCl}_{3}{ }^{[16]}$. ${ }^{13} \mathrm{C}$ NMR Table (1) showed 40 carbon signals. The Attached Proton Test (APT) spectrum exhibited 10 methyls, 15 methylenes, 8 methines, and 7 quaternary carbons. Seven signals of the dammara moiety were assigned to methyl carbons at $\left[\mathrm{C}-18\left(\delta_{\mathrm{c}} 14.768\right), \mathrm{C}-19\left(\delta_{\mathrm{c}} 16.351\right), \mathrm{C}-26\left(\delta_{\mathrm{c}} 15.58\right), \mathrm{C}-27\right.$ $\left(\delta_{\mathrm{c}} 17.57\right), \mathrm{C}-28\left(\delta_{\mathrm{c}} 28.267\right), \mathrm{C}-29\left(\delta_{\mathrm{c}} 18.199\right)$, and C-30 $\left.\left(\delta_{\mathrm{c}} 18.199\right)\right]$. Two oxygen-substituted carbons were observed at C-1 $\left(\delta_{\mathrm{c}} 215\right)$ and $\mathrm{C}-3\left(\delta_{\mathrm{c}} 79.045\right)$. In addition, an olefinic carbon was detected at C-20 $\left(\delta_{\mathrm{c}} 151.24\right)$. This data, in combination with the ${ }^{1} \mathrm{H}$ - NMR signals spectrum of compound Table (1), showed 7 methyl groups at $[\delta 0.949(3 \mathrm{H}, s), 0.90(3 \mathrm{H}, s), 0.886(3 \mathrm{H}, s), 0.833(3 \mathrm{H}, s), 0.793(3 \mathrm{H}, s), 0.77(3 \mathrm{H}, s), 1.265(3 \mathrm{H}, s)$ and one doublet of terminal olefinic protons at $\delta 4.57\left(d, J_{g e m}=2, \mathrm{H}-21 \mathrm{a}\right)$ and $\delta 4.69\left(d, J_{g e m}=2, \mathrm{H}-21 \mathrm{~b}\right){ }^{[17]}$. A one oxymethine proton resonates in doublet of doublet at $\delta 3.18$ (H-3a) with a coupling constant $11 \mathrm{~Hz}$ and $5.5 \mathrm{~Hz}$ which indicated that $\mathbf{C}$ exhibited $\beta$-oriented hydroxyl group ${ }^{[18]}$ with absence of signal at $\delta 5.39$ of olefinic bond at $\mathrm{C}-12$ which prove $12-13$ dihydro dammarane type triterpene and two olefinic proton at $\mathrm{H}-21\left(\delta_{\mathrm{H}} 4.57,1 \mathrm{H}\right.$, brs- $\mathrm{H}-21 \mathrm{a}$ and $\delta_{\mathrm{H}} 4.69,1 \mathrm{H}$, brs- $\left.\mathrm{H}-21 \mathrm{~b}\right)$, suggested that it was a dammarane-type triterpene ${ }^{[19,20]}$.

${ }^{13} \mathrm{C}$ NMR spectrum was similar to that of triterpenoid dammarane type; but downfield shifts for $\mathrm{C}-1(\delta$ $=215)$ featured an additional one oxygenated quaternary carbon atom $(\delta=215$ for $\mathrm{C}-1)$ and absence of $\mathrm{H}$ 1.These results confirm the position of the carbonyl group at C-1. Allocation of this proton was clearly established by HSQC experiments, which showed correlations of $\mathrm{H}-21 \mathrm{a} \mathrm{H}-21 \mathrm{~b}(\delta=4.57$ brs, 4.69 brs $)$ with carbon signal at $\delta=109.503(\mathrm{C}-21)$. The ${ }^{13} \mathrm{C}$ NMR and APT spectra revealed an olefinic methine carbon resonance at $\delta=151.240(\mathrm{C}-20)$, whereas seven quaternary carbon resonances at $215,41.045,43.064,37.405$, 43.238, 151.240 and $192.0 \mathrm{ppm}$ could be assigned to C-1, C-4, C-8, C-10, C-14, C-20 and C-1', respectively Table (1). The ${ }^{1} \mathrm{H}$ and ${ }^{13} \mathrm{C}$ signals were fully assigned according to heteronuclear single quantum correlation (HSQC) spectra Table (1). The NMR data of the compound skeleton were compared with related structure to those of ixorene 3-isovalarate and ixorene $3{ }^{`}, 8^{`}$-dimethyloctanoate ${ }^{[21]}$ that show certain similarity with two exception firstly; the absence $\delta_{\mathrm{c}} 121,142$ of double bond between C-12, 13 and the second difference presence of downfield shift of carbon resonance signal of C-1 $\left(\delta_{\mathrm{c}} 215\right)$ which confirm other oxygen substituted carbon. The side chain containing gem methyls group appear in IR spectrum at $1380 \mathrm{~cm}^{-1}$ and showing two doublet at $\delta$ $0.85(J=6.5, \mathrm{H}-26)$ and $\delta 0.82(J=6.5, \mathrm{H}-27)$ in NMR with the one bond correlations with $\delta_{\mathrm{c}} 22.70$ and $\delta_{\mathrm{c}} 19.75$ in HSQC plot. The spectral data for ring A, B, C and D completely agree with those reported dammarane teriterpene $\mathrm{e}^{15,22]}$. The 17 $\beta$-substituted configuration of the side chain is based on downfield chemical shift at $\delta$ $2.35 \mathrm{~m}(\mathrm{H}-17)^{[15,22-24]}$. All of above data led to fully identify the compound as $17 \beta$-dammara 20 ene- $3 \beta$-ol ${ }^{[14]}$.

The side chain at C-3; methylene alpha to the ester group is at $2.4 \mathrm{ppm}$ and the remaining $\mathrm{CH}_{2}$ group protons have similar resonance frequencies and overlap in the range of $1.2-1.6 \mathrm{ppm}$. The integral of this region is proportional to the total number of these $\mathrm{CH}_{2}$ protons ${ }^{[25]}$. Four aliphatic methylenes in a single signal, two methine and two terminal methyl groups; integration of these signals indicated that the substituent at position 1'. The ${ }^{13} \mathrm{C}$ NMR data showed ten signals for the 10 carbon atoms arising from aliphatic carbons. The assignment of the protonated carbons, C-2', C-3', C-4', C-5', C-6', C-7', C-8' and C-9', $10^{\prime}$ was made from a ${ }^{13} \mathrm{C} /{ }^{1} \mathrm{H}$ chemical shift correlation experiment and one due to a methylene dioxy group at $\delta_{\mathrm{c}} 192.0$. Therefore the $\delta_{\mathrm{c}}$ from C-2' to C-10' suggest that ${ }^{13} \mathrm{C}$ NMR resonances at $48.3,38.472,29.684,49.238,40.02,38.098,38.098,19.743$ and 18.199 respectively. Table(1) all data of the side chain similar to the reported data of $17 \beta$-dammara-12, 20

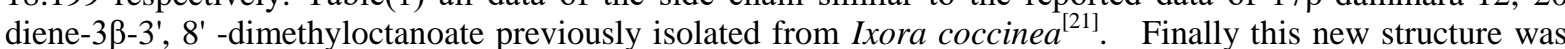

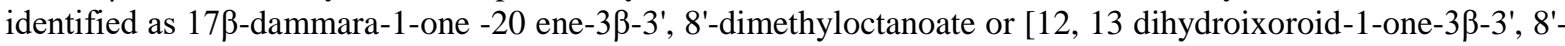
dimethyloctanoate] (1) Fig. (2).

Also, isolation of two known saturated fatty acids capric (2) ${ }^{[26]} \&$ palmitic $(\mathbf{3})^{[26]}$, from the chloroform extract as well as three phenolic acids: Gallic (4) ${ }^{[27]}$, Caffeic (5) ${ }^{[28,29]}$, Chlorogenic (6) ${ }^{[27,30]}$, six flavonols: Kaempferol 3-O- $\beta$-D-arabinopyranoside (7) ${ }^{[31]}$, afzelin (8) ${ }^{[32,33]}$, Kaempferol-3- $O$ - $\beta$-glucopyranosyl-7- $O$ glucuropyranoside (9) ${ }^{[31]}, \quad$ Kaempferol-3-O- $\alpha$-L-rhamnopyranosyl $(1 " ' \rightarrow 6 ")(4 "$-trans-p-coumaroyl) $\beta$-D glucopyranoside-7- $O$ - $\alpha$-L-rhamnopyranoside $(\mathbf{1 0}){ }^{[34]}$, Kaempferol-3- $O$ - $\alpha$-L-rhamnopyranosyl $(1 " ' \rightarrow 2 ")(4 "-$ trans-p-coumaroyl) $\beta$-D-arabinopyranosid-7- $O$ - $\alpha$-L-rhamnopyranoside (11) ${ }^{[34]}$, and Kaempferol (12) ${ }^{[35]}$. Also, two isoflavones: Biochanin A (13) ${ }^{[36]}$, Biochanin A-7- $O-\beta$-D-rutinoside (14) ${ }^{[37]}$, were isolated from methanol extract. All these compounds were isolated for the first time from Ixora finlaysoniana leaves and were elucidated by different chromatographic and spectroscopic techniques; UV, extensive 1D and 2D NMR and MS in comparison with previous published data ${ }^{[26-37]} \cdot \mathrm{LD}_{50}$ of both leaves and aqueous extracts of the aerial parts were $(8.4 \mathrm{gm} / \mathrm{Kg} \mathrm{b.wt}$.) and $(7.8 \mathrm{gm} / \mathrm{Kg}$ b.wt.), respectively. Therefore, all tested samples are safe in the range of used doses. In vivo studies of Ixora finlaysoniana Wall. ex G. Don exhibited different biological activities of the tested samples which is useful in treating certain disease as peptic ulcer, seizures, diabetes and liver diseases. 
Anti-ulcer activity; results in Table (2) and Fig. (3), obviously showed potent effect where all tested samples are significantly considered safe on gastric mucosa, where ulcer number was negligible in comparison with ulcerogenic standard indomethacin .

Anticonvulsant activity; results in Table (3) and Fig. (4) revealed variable and significant efficacy where all tested samples at pre-mentioned doses significantly increased the voltage needed to induce an electric shock after treatment when compared with Carbamazepin standard. Both leaves alcohol extract and the aqueous extract of aerial parts of Ixora finlaysoniana Wall. ex G. Don showed higher activity in increasing the voltage needed to induce an electric shock so, exhibited anticonvulsant activity, and by more clinical trials it may be involved in many antiepileptic drugs in the future.

Antihyperglycemic and antioxidant activity; From Table $(4,5)$ and Fig. $(5,6)$ it could be concluded that, Cidophage at a dose $(150 \mathrm{mg} / \mathrm{Kg}$ b. wt.) significantly reduced the blood glucose level of induced diabetic rats after two and four weeks by $(43.47 \%$ and $66.1 \%)$, respectively. Tested samples significantly reduced the blood glucose level of induced diabetic rats by $(35 \%, 33.7 \%, 20 \%, 16.3 \%, 32.7 \%, 25.5 \%, 28.8 \%$ and $22.9 \%$ after two weeks), (51.5\%, 47.2 \%, $26.6 \%, 24.4 \%, 43.9 \%, 42.3 \%$ after four weeks), respectively. Both leaves alcohol extract and the aqueous extract of aerial parts of Ixora finlaysoniana Wall. ex G. Don showed potent antidiabetic activity. Ixora showed strong antihyperglycemic activity and restored blood glutathione level in diabetic rats due to their strong antioxidant effect, this study prove claim of use it in Indian folk medicine. Finally, it is concluded that the total alcoholic extract of Ixora finlaysoniana leaves possesses antidiabetic activity but there is a need of evaluation with proven clinical trials.

Animals treated with Vitamin E $(7.5 \mathrm{mg} / \mathrm{Kg} \mathrm{b}$. wt.) restored the level of blood glutathione in diabetic rats. The level of blood glutathione in diabetic rats was restored after the oral administration of the tested samples. All tested samples possessed a powerful antioxidant activity. Effect may be due to effect of phenolics compounds in all samples. Both leaves alcohol extract and the aqueous extract of aerial parts of Ixora finlaysoniana Wall. ex G. Don showed higher antioxidant activity.

Hepatoprotective activity; Chronic liver diseases commonly result in liver fibrosis and oxidative stress is the common mechanism contributing in the initiation and progression of hepatic damage in a variety of liver disorders. Carbon tetrachloride $\left(\mathrm{CCl}_{4}\right)$ is widely used for experimental induction of liver fibrosis. $\mathrm{CCl}_{4}$ is a potent hepatotoxin producing centrilobular necrosis, which causes liver injury ${ }^{[38]}$. Since the changes associated with $\mathrm{CCl}_{4}$-induced liver damage are similar to those of acute viral hepatitis ${ }^{[39]}$. $\mathrm{CCl}_{4}$-mediated hepatotoxicity was chosen as the experimental model. The ability of a hepatoprotective drug to reduce the injurious effects or to preserve the normal hepatic physiological mechanisms, which have been disturbed by a hepatotoxin, is the index of its protective effects ${ }^{[40]}$.

Liver damage induced by $\mathrm{CCl}_{4}$ involves biotransformation of free radical derivatives, increased lipid peroxidation and excessive cell death in liver tissue ${ }^{[41]}$. The toxic effects of $\mathrm{CCl}_{4}$ on liver have been extensively studied. Serum AST and ALT are the most sensitive biomarkers used in the diagnosis of liver diseases ${ }^{[42]}$. During hepatocellular damage, varieties of enzymes normally located in the cytosol are released into the blood flow. Their quantifications in plasma are useful biomarkers of the extent and type of hepatocellular damage so; increased levels of ALT, AST, and ALP are conventional indicators of liver injury. The prevention of this phenomenon can be considered as hepatoprotective activity ${ }^{[43]}$. The results are illustrated in Table $(6,7$ and 8$)$ and Fig. (7, 8 and 9).It could be concluded that, silymarin at a dose $(25 \mathrm{mg} / \mathrm{Kg} \mathrm{b}$. wt.) as a standard significantly reduced the serum AST, ALP and ALT after $72 \mathrm{hrs}$ after administration of carbon tetrachloride by $(57.4 \%$, $60.5 \%$ and $56.2 \%)$ and then after 1 week $(78.3 \%, 88.7 \%$ and $75.7 \%)$, respectively. After oral administration of the tested samples of the plant under investigation and standard, serum AST, ALP and ALT were collected and the percentage of change in function of liver were calculated after $72 \mathrm{hrs}$ of administrating carbon tetrachloride were recorded and compared to standard silymarin. Total leaves alcohol extract of Ixora finlaysoniana Wall. ex G. Don showed higher hepatoprotective activity.

For the therapeutic strategies of liver injury and disease, it is important to find antioxidant compounds that are able to block liver injuries through free radicals generated due to toxic chemicals. Therefore, the present study speculated that the total alcoholic extracts of Ixora finlaysoniana leaves protect against diseases that are caused by reactive oxygen species (ROS) because it has radical scavenging ability based on its antioxidant activity against $\mathrm{CCl}_{4}$ in mice which developed significant hepatic damage as manifested by a significant increase in activities of AST, ALT and ALP concentration that are indicators of hepatocyte damage and loss of functional integrity ${ }^{[44]}$. The metabolic transformation of $\mathrm{CCl}_{4}$ by the NADPH-cytochrome P-450 system to form the trichloromethyl radical which is further converted to a peroxy radical. These free radicals readily react with polyunsaturated fatty acids of the endoplasmic reticulum and other hepatocellular membranes to initiate the formation of organic lipid peroxides. In the presence of cellular $\mathrm{O}_{2}$, these organic peroxy radicals in turn can react with other polyunsaturated fatty acids to perpetuate a series of self-propagating chain reactions, known as "propagation of lipid peroxidation". In addition, it has been shown that $\mathrm{CCl}_{4}$-induced toxicity may stimulate endogenous reactive oxygen and nitrogen species that have also been suggested to play an important role in the 
pathogenesis of hepatotoxicity. Enhanced lipid peroxidation may be associated with depletion of the antioxidant; $\mathrm{GSH}$ that found in the heart tissues of $\mathrm{CCl}_{4}$ treated mice which are a characteristic observation in $\mathrm{CCl}_{4}$-intoxicated mice. GSH is important in detoxification of the reactive metabolites of cells; tissue necrosis is initiated when the reserves of GSH are markedly depleted. Thus, the reduced (relative to normal) levels of GSH observed in the heart tissues of $\mathrm{CCl}_{4}$ intoxicated mice might be a reflection of increased oxidative damage ${ }^{[44,45]}$. Antioxidant enzymes activities in liver of $\mathrm{CCl}_{4}$-treated group mice were significantly lower than those in normal control group. Antioxidant enzymes SOD (enzymes that catalyze the conversion of two superoxides into oxygen and hydrogen peroxide which substantially less toxic than superoxide) and CAT (enzymes which degrade hydrogen peroxide to water and oxygen, and hence finish the detoxification reaction started by SOD.) represent one of the protection mechanisms against oxidative tissue-damage.

The administration of the total alcoholic extract of Ixora finlaysoniana leaves caused an elevation of the levels of GSH in the liver in serum suggesting that it can restore these antioxidant enzymes and/or reactivate enzyme after the damage caused by $\mathrm{CCl}_{4}$. In conclusion, this study showed that the total alcoholic extract of Ixora finlaysoniana leaves has a remarkable protective effect against $\mathrm{CCl}_{4}$-induced liver injury in mice and its mechanism is related, at least in part, to its free radical scavenging and antioxidant activities.

\section{Conclusion}

Dammarane is a group of triterpenoids isolated from various plants and exhibited valuable biological activities such as antitumor, anti-inflammatory, immunosuppressive and antitubercular ${ }^{[4,21]}$; so further studies are needed in order to establish the effect and action mechanisms of the isolated new compound responsible for these biological effects to obtain additional information on the structural factors needed for the potent activity. After illustrating the activities done on Ixora finlaysoniana; it could be concluded that the total alcohol extract, the total aqueous extract (as given in folk medicine) has highest biological activities compared to other fractions give Ixora finlaysoniana great potential and supporting to use it as a source of natural raw material for phytopharmaceuticals preparations as the new coming treatment since it is an effective safe as hepatoprotective, antiulcer, anticonvulsant, antioxidant and anti-diabetic herbal drug.

This article abstracted from PhD of Asmaa I. Ali, Pharmacognosy Department, Faculty of Pharmacy, Misr International University, Cairo, Egypt

\section{References}

[1] A. Elumalai, C. Eswaraiah, Y. Venkatesh, B.S. Kumar and C. Narendar. Phytochemical and pharmacological profile of Ixora coccinea Linn. Int J of Pharm and Life Sci. 3(3), 2012, 1563-1567.

U.O. Gloria and U.N. Gibson. Chemical composition of essential oil of Ixora coccinea flower from Port Harcourt, Nigeria. International Journal of Academic Research. 3(2), 2011, 381-384.

[3] M.M. Faten and Z.I. Zedan. Phytochemical study of Ixora finlaysoniana wall. Ex. G. Don. growing in Egypt. Bull Pharm Sci. 26(1), 2003, 91-96.

[4] I A. Asmaa, T. I. Magda, M. Khaled, T. Abeer and S. Amany. Composition and Bioactivities of the Essential oil of Ixora finlaysoniana Wall. ex G. Don. (Family Rubiaceae). Journal of Oil Bearing Plants. 18 (4), 2015, 754-766.

[5] T.J. Mabry, K.R. Markham, and M.B. Thomas. The systematic identification of flavonoids. Springer Verlag, Berlin, 1970, 41164.

[6] G. Karber. Determination of median leathal dose. Arch Exp. Pathol. Parmacol. 162: 1931, 480-487.

[7] T.K. Corell, K.M. Jensen, and S.J.B. Splowyni. A new anti-inflammatory derivative of imidazole which is less ulcerogenic than indomethacin in rats. Acta Pharmacol et Toxicol. 45: 1979, 232-239.

[8] P. Alberto, Arch. Exp. Pathol. Pharmacol. 15: 1982, 248-251.

[9] E. Beutler, O. Duron, and B.A. Kelly. Improved method for the determination of blood glutathione. J. lab. Clin. Med. 61: 1963, 882-888.

[10] P. Trinder, Estimation of serum glucose and triglycerides by enzymatic method. Am. Clin. Biochem. 1969; 6: 24-27.

[11] W. Thewfweld, Enzymatic method for determination of serum AST, ALT and ALP. Dtsch Med. 99: 1974, $343-347$.

[12] P.R. Kind, and E.G. King. A colourimetric method for the determination of serum alkaline phosphatase. J. Clin. Path. 7: 1954, 322 326.

[13] C.D. Klassen, and G.L. Plaa, Comparison of the biochemical alteration elicited in liver of rats treated with $\mathrm{CCl}_{4}$ and $\mathrm{CHCl}_{3}$. Toxic Appl. Pharmacol. 18: 1969, 2019-2030.

[14] W.G. Snedecor, and G.W. Cochran. Statistical methods, $1982.10^{\text {th }}$ ed., lowa state, University, Press, USA

[15] S.C. Sharma and J.S. Tandon. Dammarane triterpene from Commelina undulate. Phytochemistry. 21, 1982, $2420-2421$.

[16] H. Chavez, A.E. Braun, A.G. Ravelo and G.A. Gonzalez. First examples of Dammarane triterpene isolated from Celastraceae. Tetrahedron. 53, 1997, 6465-6472.

[17] A. Ulubelen, S. Oksuz and E. Tuzlaci. A new triterpene and others compound from Achillea magnifica. Planta Med. 55, 1989, 395.

[18] J. J. Magadula, D.A. Mulholland and N.R. Crouch. Triterpenoid from Anthocleista grandiflora (Gentianaceae). Nat. Pro. Comm. 3, 2008, 885-889.

[19] K.K. Li, X.B. Yang, J.X. Liu and X.J. Gong. New triterpenoids from the stems and leaves of Panax ginseng. Fitoterapia, 83, 2012, 1030-1035.

[20] T.R. Yang, R. Kasai, J. Zhou and O. Tanaka. Dammarane saponins of leaves and seeds of Panax notoginseng. Phytochemistry. 22, 1983, 1473-1478.

[21] A. Ikram, M.A. Versiani, A. Khatoon, S.K. Ahmed, S.A. Sattar and S. Faizi. New dammarane and ursane-type triterpenoids from the flower of Ixora coccinea Linn. Nat Prod Res. Jul 27, 2015, 1-8. 
[22] L. Revesz, P. Hiestand, L.L. Vecchia, R. Naef, H.U. Naegali, L. Oberer and H.J. Roth. Isolation and synthesis of a novel immunosuppressive 17alpha-substituted dammarane from the flour of the Palmyrah palm (Borassus flabellifer). Bioorg Med Chem Lett. Jun 7; 9(11), 1999, 1521-1526.

[23] I. Kubo and K. Fukhara. A new cytotoxic triterpene from an east African medicinal plant Eleodenron buchanii. J. Nat. Prod. 53, 1990, 968-971.

[24] J. D. P. Teresa, I. S. Bellido, M. S. Gonzalez and S. Vicente. Tetracyclic triterpene and nerolidol derivatives from Santolina oblongifolia. Phytochemistery. 25, 1986, 185-190.

[25] T.H. Marc, U. Stephanie B. Rachel and M. Christina. Using proton nuclear magnetic resonance as a rapid response tool for methyl ester characterization in biodiesel. Lipid technology. Februray 21(2), 2009, 1-3.

[26] A.S. Mellidis and V.P. Papageorgiou. Lipids from roots of Onosma heterophylla. Phytochemistry, 26, (3), 1987, 842-843.

[27] D. Nedime, O. Seckin, U. Esra, D. Yasar, K. Mustafa. The isolation of carboxylic acids from the flowers of Delphinium formosum. Turk J Chem. 25, 2001, 93-97.

[28] B. Bahawana. Chemical constituents of Solanum xanthocarpum. J. Chem. Pharm. Res. 3, 2011, 176-181

[29] D. Baricevic, S. Sosa, L.R. Della, A. Tubaro, B. Simonovsha, Krasna and A. J. Zupancic. Ethnopharmacol. 75, 2001, 32-125

[30] J. B. Harborne, The Flavonoids: Advances in Research Since1986, Chapman and Hall: London. 1994.

[31] A.B. Sajeli, S. Mahendra, F. Yoshinori, K. Asai, S. Kathrin, N. Graeme and S. Roderich. A new kaempferol diglycoside from Datura suaveolens Humb. \& Bonpl. ex. Willd. Natural Product Research 20, 2006, 1231-1236.

[32] O.A. Eldahshan. Isolation and structure elucidation of phenolic compounds of Carob leaves grown in Egypt. Current Research Journal of Biological Sciences 3(1), 2011, 52-55.

[33] E. Rakib, H. Chicha, S. Abouricha, M. Alaoui, A.A. Bouli, M. Hansali and R.W. Owen, Determination of phenolic composition of carob pods grown in different regions of Morocco. J. Nat. Prod., 3, 2010, 134-140.

[34] Z. Ying-Jun, X. Sui-Xu, C. Qing-Ming and S. Qi-Shi. Flavonoids from the leaves of Quercus dentate. Indian Journal of Chemistry (40B) May 200l, 394-398.

[35] R.K. Bachheti, D.P. Pandey, A. Joshi, V. Rana and I. Rai. Phytochemical analysis of aerial parts of Ixora parviflora. Int J Chem Tech Res. 3(3), 2011, $1028-1032$.

[36] V. C. Da Silvaa, Mário G. C. and Sandra L. D C. E Silva. Chemical constituents from roots of Andira anthelmia (Leguminosaea) Rev. Latinoamer. Ouím. 35(1 ),2007,13-19

[37] M.S. Marzouk, T.I. Magda, O.D. El- Gindi and S.A. Marwa. Isoflavonoid glycosides and rotenoids from Pongamia pinnata leaves Z. Naturforsch 63c, 2008, 1-7.

[38] A. A. A. Khalaf, M. E. M. Mekawy, M. S. Moawad, and A. M. Ahmed. Comparative study on the protective effect of some antioxidants against $\mathrm{CCl}_{4}$ hepatotoxicity in rats. Egyptian Journal of Natural Toxins, 6, (1), 2009, $59-82$.

[39] S.R. Suja, P.G. Latha, P. Pushpangadan, S. Rajasekharan Evaluation of hepatoprotective effects of Helminthostachys zeylanica (L.) Hook against carbon tetrachloride-induced liver damage in Wistar rats. J. Ethnopharmacol., 92: 2004, 61-66.

[40] N.P. Yadav, V.K. Dixit. Hepatoprotective activity of leaves of Kalanchoe pinnata Pers. J. Ethnopharmacol., 86: 2003 , $197-202$.

[41] R.O. Recknagel. A new direction in the study of carbon tetrachloride hepatotoxicity. Life Sci. 33: 1983, 401-408.

[42] L. Pari and A.N. Kumar. Hepatoprotective activity of Moringa oleifera on antitubercular drug-induced liver damage in rats J. Med. 2002; 5:171-177.

[43] L. Pari and P. Murugan. Protective role of tetrahydrocurcumin against erythromycin estolate-induced hepatotovicity. Pharmacol. Res. 2004; 49:481-486.

[44] R. Li, W. Guo, Z. Fu, G. Ding, Y. Zou and Z. Wang. Hepatoprotective action of Radix Paeoniae Rubra aqueous extract against $\mathrm{CCl}_{4}$-induced hepatic damage. Molecules, 16(10), 2011, 8684-8693.

[45] M.G. Krishna, E. Pallavi, K.B. Ravi, M. Ramesh and S. Venkatesh. Hepatoprotective activity of Ficus carica (Linn) leaf extract against carbon tetrachloride-induced hepatotoxicity in rats. DARU. 2007; 15(3), 162-167.

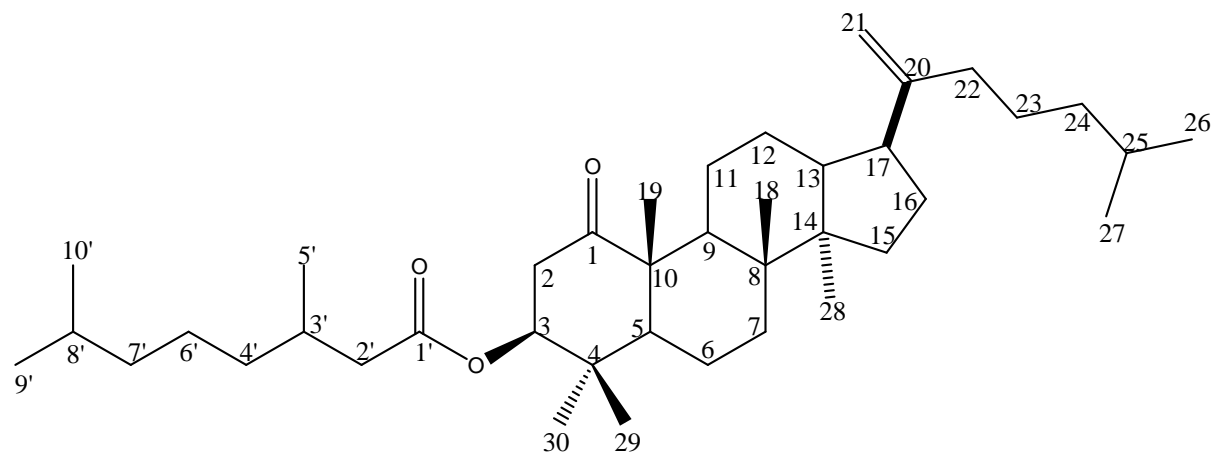

Figure (2): Dammarane Triterpenoid (17 $\beta$-dammara-1-one-20ene-3 $\beta-3$ ', 8' dimethyl octanoate)

$\underline{\text { OR }}(12,13$ dihydroixoroid-1-one-3 $\beta-3$ ', 8' dimethyl octanoate)

Table (1): NMR spectroscopic data for new compound (300 $\mathrm{MHz}$ for ${ }^{1} \mathrm{H}$ and $100 \mathrm{MHz}$ for ${ }^{13} \mathrm{C}, \mathrm{CDCl}_{3}$ )

\begin{tabular}{|c|c|c|c|c|c|}
\hline Побıนเор & $\delta \mathrm{H}$ & $\delta \mathrm{X}$ & Побıтเор & $\delta \mathrm{H}$ & $\delta \mathrm{X}$ \\
\hline 1 & - & 215 & 21 & $\begin{array}{l}4.57 \beta \rho \sigma \mathrm{H}-21 \alpha \\
4.69 \beta \rho \sigma \mathrm{H}-21 \beta\end{array}$ & 109.503 \\
\hline 2 & $1.689 \delta \delta$ & 28.267 & 22 & $1.3 \mu$ & 29.68 \\
\hline 3 & $3.18 \delta \delta(\vartheta=5.5,11 H \zeta)$ & 79.045 & 23 & $1.208 \mu$ & 29.68 \\
\hline 4 & - & 41.064 & 24 & $1.26 \mu$ & 29.68 \\
\hline 5 & $0.74 \sigma$ & 55.473 & 25 & $1.26 \sigma$ & 34.5 \\
\hline 6 & $1.302 \mu$ & 21.201 & 26 & $0.886 \sigma$ & 15.58 \\
\hline 7 & $1.26 \mu$ & 34.502 & 27 & $0.833 \sigma$ & 15.57 \\
\hline
\end{tabular}




\begin{tabular}{|llllll|}
\hline 8 & - & 43.064 & 28 & $0.793 \sigma$ & 28.267 \\
9 & $1.26 \mu$ & 50.547 & 29 & $0.74 \sigma$ & 18.199 \\
10 & - & 37.405 & 30 & $1.265 \sigma$ & 18.199 \\
11 & $1.62 \mu$ & 27.63 & $1 \ni$ & - & 192 \\
12 & $1.26 \mu$ & 28.819 & $2 \ni$ & $2.43 \delta \delta(\vartheta=7.5,15 H \zeta)$ & 48.3 \\
13 & $1.175 \mu$ & 35.819 & $3 \ni$ & $1.63 \mu$ & 38.472 \\
14 & - & 43.238 & $4 \ni$ & $0.973 \sigma$ & 29.684 \\
15 & $1.654 \mu$ & 39.098 & $5 \ni$ & $1.854 \sigma$ & 49.238 \\
16 & $1.2 \sigma$ & 34.5 & $6 \ni$ & $1.89 \mu$ & 40.02 \\
17 & $2.35 \mu$ & 48.238 & $7 \ni$ & $1.918 \mu$ & 38.098 \\
18 & $0.949 \sigma$ & 14.768 & $8 \ni$ & $1.963 \mu$ & 38.098 \\
19 & $0.900 \sigma$ & 16.351 & $9 \ni$ & $0.973 \delta(\vartheta=6.5 H \zeta)$ & 19.743 \\
20 & - & 151.240 & $10 \ni$ & $1.003 \delta(\vartheta=6.5 H \zeta)$ & 18.199 \\
\hline
\end{tabular}

Table (2): Anti-ulcer activity of the tested samples of Ixora finlaysoniana Wall. ex G. Don.:

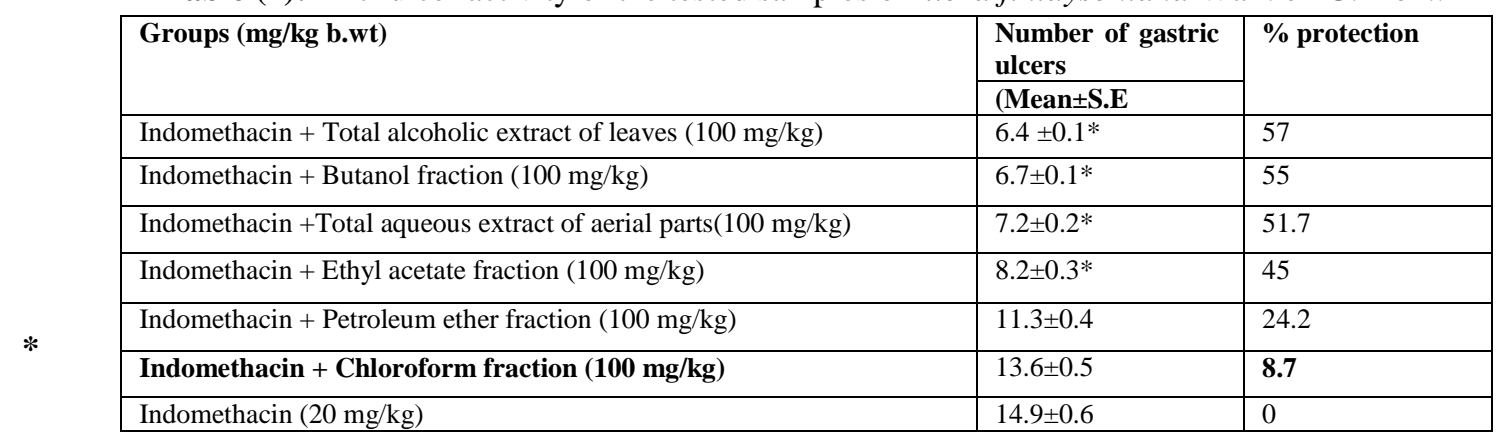

Statistically significant from the control at $\mathrm{p}<0.01$.

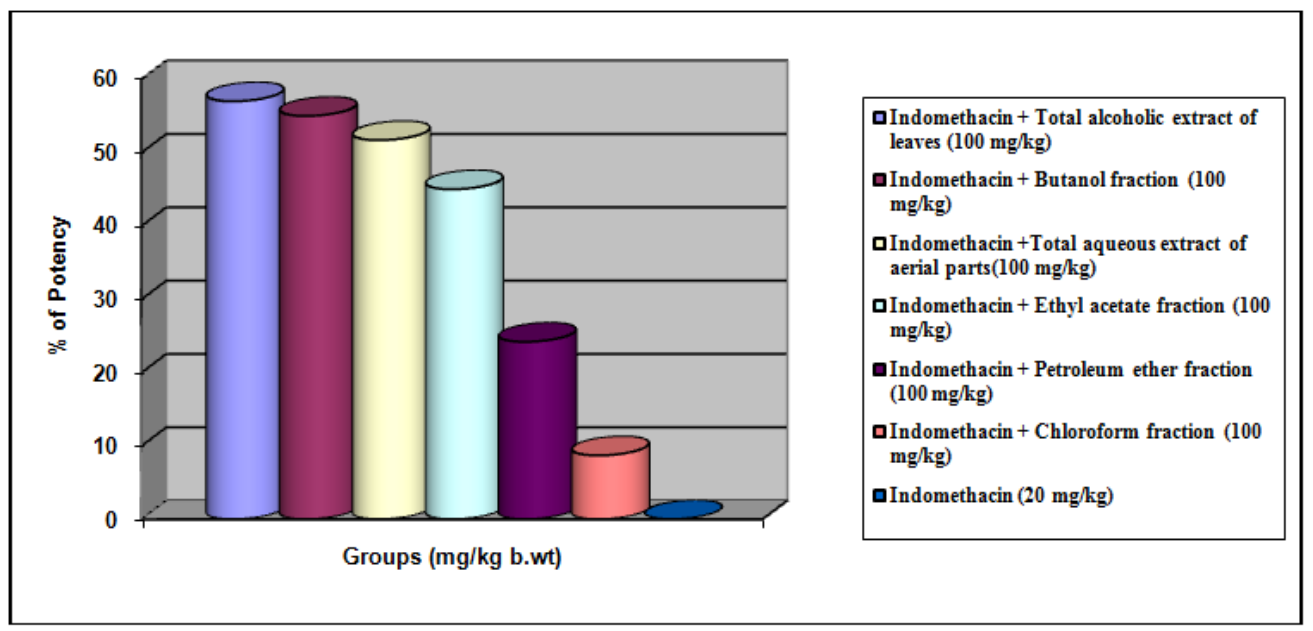

Figure (3): Anti-ulcer activity of the tested samples of Ixora finlaysoniana Wall. ex G. Don.

Table (3): Anticonvulsant activity of the tested samples of Ixora finlaysoniana Wall. ex G. Don.:

\begin{tabular}{|l|l|l|l|}
\hline Groups (mg/kg b.wt) & $\begin{array}{l}\text { Volts induced } \\
\text { seizures }\end{array}$ & \multirow{2}{*}{$\begin{array}{l}\text { \% change } \\
\text { potency }\end{array}$} \\
\cline { 2 - 3 } & Mean \pm S.E. & & \\
\hline Carbamazepin(100mg/kg) & $11.7 \pm 0.9^{*}$ & 387.5 & 100 \\
\hline Total alcoholic extract of leaves $(\mathbf{1 0 0 m g / k g )}$ & $8.3 \pm 0.4^{*}$ & 245.8 & $\mathbf{6 3 . 4}$ \\
\hline Total aqueous extract of aerial parts $(100 \mathrm{mg} / \mathrm{kg})$ & $7.9 \pm 0.3^{*}$ & 229.2 & 59.1 \\
\hline Ethyl acetate fraction $(100 \mathrm{mg} / \mathrm{kg})$ & $7.4 \pm 0.2^{*}$ & 208.3 & 53.8 \\
\hline Butanol fraction $(100 \mathrm{mg} / \mathrm{kg})$ & $5.9 \pm 0.3^{*}$ & 145.8 & 37.6 \\
\hline Chloroform fraction $(100 \mathrm{mg} / \mathrm{kg})$ & $3.4 \pm 0.1^{*}$ & 41.7 & 10.8 \\
\hline Petroleum ether fraction $\mathbf{( 1 0 0 ~} \mathbf{~ m g / k g ) ~}$ & $3.3 \pm 0.1^{*}$ & 37.5 & $\mathbf{9 . 7}$ \\
\hline Control $(1 \mathrm{ml}$ saline) & $2.4 \pm 0.1$ & --------- & -------- \\
\hline
\end{tabular}

* Statistically significant from the control at $\mathbf{p}<0.01$. 


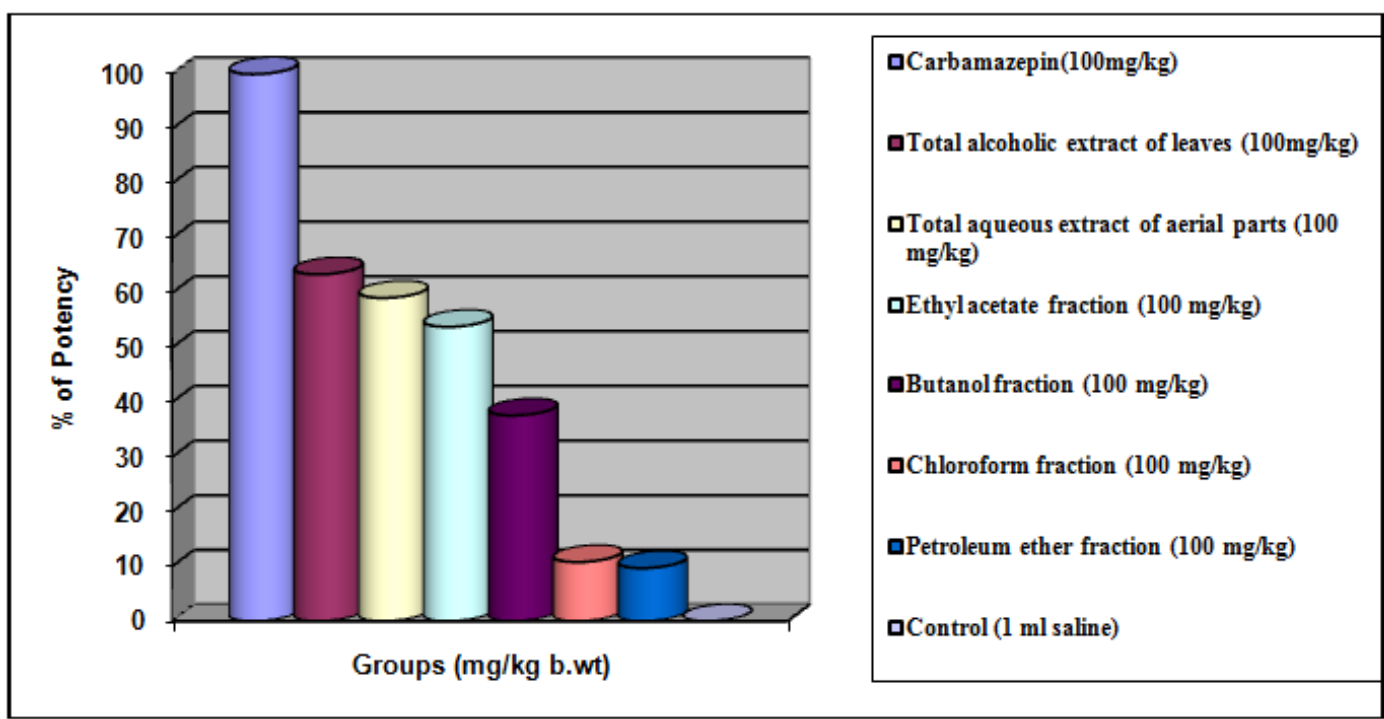

Figure (4): Anticonvulsant activity of the tested samples of Ixora finlaysoniana Wall. ex G. Don.

Table (4): Antioxidant activity of the tested samples of Ixora finlaysoniana Wall. ex G. Don.:

\begin{tabular}{|c|c|c|c|}
\hline \multirow[t]{2}{*}{ Animal Group $(n=6)$} & \multicolumn{3}{|c|}{ Blood glutathione (mg \%) } \\
\hline & Mean \pm S.E. & \% of change & \% of potency \\
\hline Diabetic + Vitamin E $(7.5 \mathrm{mg} / \mathrm{kg})$ & $35.9 \pm 1.1$ & 67.8 & 100 \\
\hline Diabetic + Total alcoholic extract of leaves $(100 \mathrm{mg} / \mathrm{kg})$ & $35.3+0.9$ & 65 & 95.9 \\
\hline Diabetic + Total aqueous extract of aerial parts $(100 \mathrm{mg} / \mathrm{kg})$ & $34.6 \pm 1.2$ & 61.7 & 91 \\
\hline Diabetic + Ethyl acetate fraction $(100 \mathrm{mg} / \mathrm{kg})$ & $34.3 \pm 1.2^{*}$ & 60.3 & 89 \\
\hline Diabetic + Butanol fraction $(100 \mathrm{mg} / \mathrm{kg})$ & $31.8 \pm 0.6^{*}$ & 48.6 & 71.7 \\
\hline Diabetic + Petroleum ether fraction $(100 \mathrm{mg} / \mathrm{kg})$ & $28.4 \pm 0.6^{*}$ & 32.7 & 48.3 \\
\hline Diabetic + Chloroform fraction. $(100 \mathrm{mg} / \mathrm{kg})$ & $26.9 \pm 0.5^{*}$ & 25.7 & 37.9 \\
\hline Control ( $1 \mathrm{ml}$ saline) & $36.3 \pm 1.4$ & ------------- & -------------- \\
\hline Diabetic & $21.4 \pm 0.3^{*}$ & 0 & ------------- \\
\hline
\end{tabular}

* Statistically significant from the control at $\mathrm{p}<0.01$.

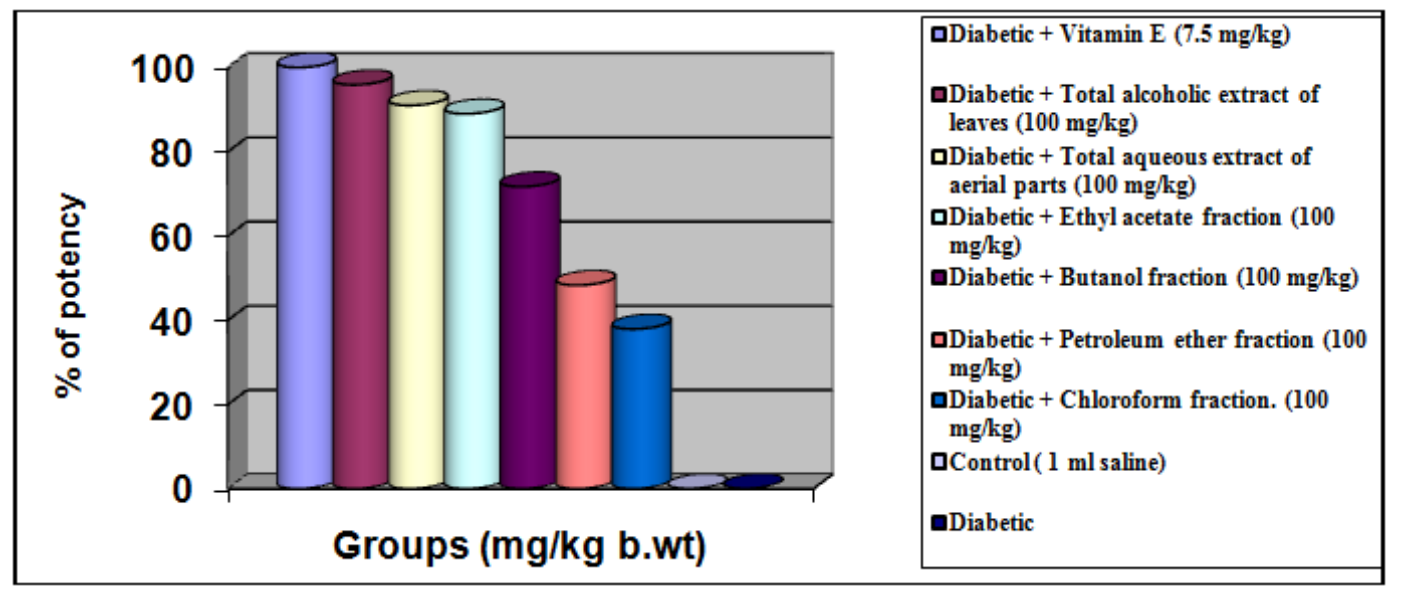

Figure (5):Antioxidant activity of the tested samples of Ixora finlaysoniana Wall. ex G 
Table (5):Chronic hypoglycemic activity of the tested samples of Ixora finlaysoniana Wall. ex G. Don.:

\begin{tabular}{|c|c|c|c|c|c|c|c|}
\hline \multirow[t]{2}{*}{ Animal Group $(\mathrm{n}=6)$} & \multirow{2}{*}{$\begin{array}{l}\text { Blood glucose } \\
\text { level before the } \\
\text { treatments }\left(G_{0}\right)\end{array}$} & \multicolumn{3}{|c|}{ After 2 weeks of treatment } & \multicolumn{3}{|c|}{ After 4 weeks of treatment } \\
\hline & & $\begin{array}{l}\text { Blood } \\
\text { glucose level } \\
\left(G_{t}\right)\end{array}$ & $\begin{array}{l}\% \\
\text { Change }\end{array}$ & $\begin{array}{l}\% \\
\text { Potency }\end{array}$ & $\begin{array}{l}\text { Blood } \\
\text { glucose level } \\
\left(\mathbf{G}_{t}\right)\end{array}$ & $\begin{array}{l}\% \\
\text { Change }\end{array}$ & $\begin{array}{l}\text { \% } \\
\text { Potency }\end{array}$ \\
\hline Control (1 ml saline) & $83.2 \pm 1.9$ & $85.4 \pm 2.3$ & $\ldots$ & - & $81.7 \pm 2.1$ & $\ldots$ & $\ldots$ \\
\hline Diabetic non treated & $251.6 \pm 8.4$ & $259.3 \pm 8.1$ & - & ב- & $266.2 \pm 9.7$ & $\overline{-1}$ & 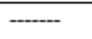 \\
\hline Metformin $(150 \mathrm{mg} / \mathrm{kg})$ & $263.4 \pm 7.9$ & $148.9 \pm 9.4^{*}$ & 43.47 & 100 & $89.3 \pm 2.6^{*}$ & 66.1 & 100 \\
\hline $\begin{array}{l}\text { Total alcoholic extract of leaves } \\
(100 \mathrm{mg} / \mathrm{kg})\end{array}$ & $251.3 \pm 7.8$ & $163.4 \pm 5.2^{*}$ & 35 & 80.5 & $121.9 \pm 4.7^{*}$ & 51.5 & 77.9 \\
\hline $\begin{array}{l}\text { Total a queous extract of aerial } \\
\text { parts }(100 \mathrm{mg} / \mathrm{kg})\end{array}$ & $261.4 \pm 8.3$ & $173.2 \pm 7.5^{*}$ & 33.7 & 77.6 & $137.9 \pm 5.4^{*}$ & 47.2 & 71.5 \\
\hline $\begin{array}{l}\text { Petroleum ether fraction (100 } \\
\mathrm{mg} / \mathrm{kg})\end{array}$ & $254.6 \pm 9.2$ & $203.7 \pm 8.5^{*}$ & 20 & 46 & $186.8 \pm 6.3^{*}$ & 26.6 & 40.3 \\
\hline Chloroform fraction $(100 \mathrm{mg} / \mathrm{kg})$ & $258.9 \pm 8.1$ & $216.7 \pm 6.4^{*}$ & 16.3 & 37.5 & $195.8 \pm 6.1^{*}$ & 24.4 & 36.9 \\
\hline Ethyl acetate fraction $(100 \mathrm{mg} / \mathrm{kg})$ & $251.6 \pm 8.4$ & $169.3 \pm 5.9^{*}$ & 32.7 & 75.2 & $141.2 \pm 4.3^{*}$ & 43.9 & 66.4 \\
\hline Butanol fraction $(100 \mathrm{mg} / \mathrm{kg})$ & $263.8 \pm 9.2$ & $196.4 \pm 6.5^{*}$ & 25.5 & 58.8 & $152.3 \pm 4.7^{*}$ & 42.3 & 63.9 \\
\hline
\end{tabular}

* Statistically significant from the control at $\mathrm{p}<0.01$.

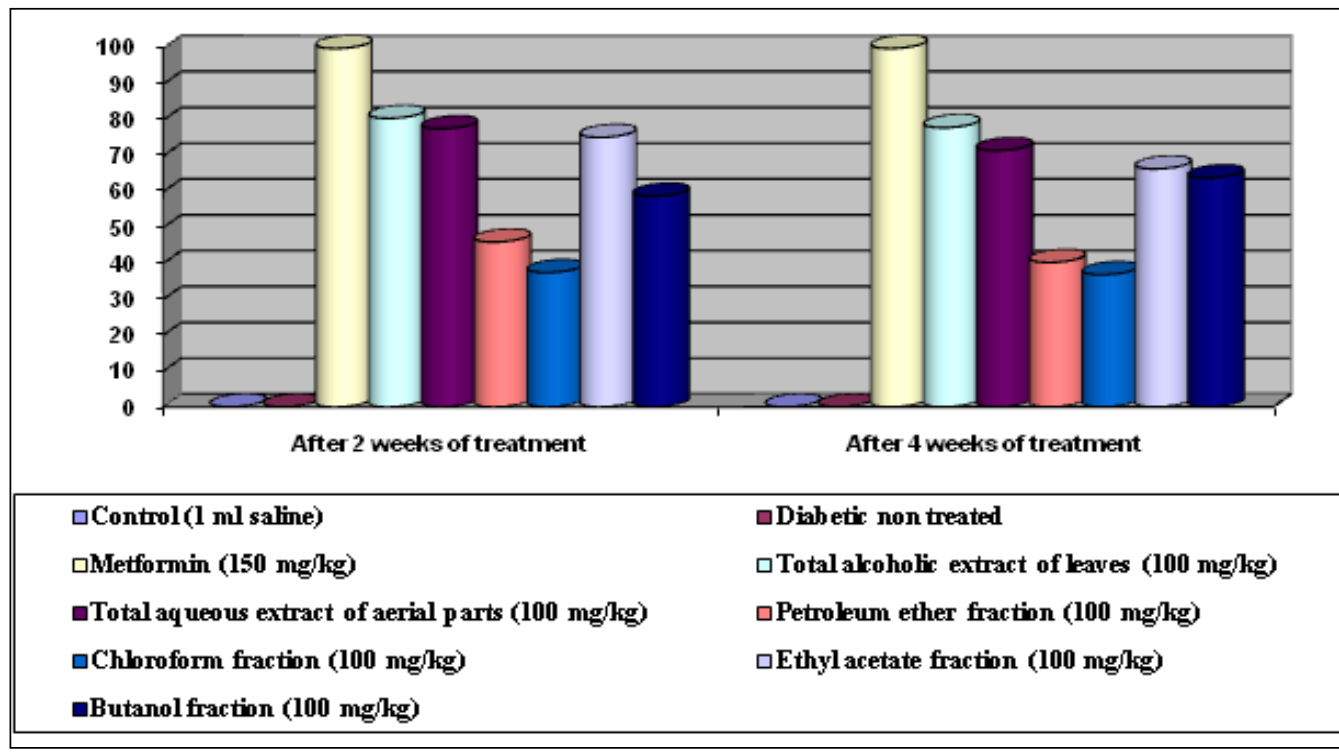

Figure (6): Chronic hypoglycemic activity of the tested samples of Ixora finlaysoniana Wall. ex G. Don.:

Table (6): Hepatoprotective activity of the tested samples of Ixora finlaysoniana Wall. ex G. Don.: (Aspartate transaminase $[\mathrm{AST}(\mathrm{m} / \mathrm{L})])$

\begin{tabular}{|c|c|c|c|c|c|c|c|c|}
\hline \multirow[t]{2}{*}{ Group } & \multicolumn{2}{|l|}{ Before } & \multicolumn{3}{|c|}{$\begin{array}{l}\% \text { of change and potency after } \\
\text { damaging liver } 72 \mathrm{hrs}\end{array}$} & \multicolumn{3}{|c|}{$\begin{array}{l}\% \text { of change and potency after } \\
\text { damaging liver } 7 \text { days }\end{array}$} \\
\hline & zero & $7 \mathrm{~d}$ & $72 \mathrm{~h}$ & $\begin{array}{l}\% \text { of } \\
\text { change }\end{array}$ & $\%$ of & $7 \mathrm{~d}$ & $\begin{array}{l}\% \text { of } \\
\text { change }\end{array}$ & $\begin{array}{l}\% \text { of } \\
\text { potency }\end{array}$ \\
\hline Control (1 ml saline) & $41.8 \pm 1.3$ & $42.9 \pm 1.8$ & $131.8 \pm 4.6^{*}$ & $\ldots$ & $\ldots$ & $161.2 \pm 3.9 \square *$ & $\ldots$ & $\ldots$ \\
\hline Silymarin $(25 \mathrm{mg} / \mathrm{kg})$ & $38.6 \pm 1.4$ & $38.8 \pm 1.7$ & $56.2 \pm 1.4^{*}$ & 57.4 & 100 & $34.9 \pm 1.10$ & 78.3 & 100 \\
\hline Total alcoholic extract of leaves $(100 \mathrm{mg} / \mathrm{kg})$ & $38.9 \pm 1.3$ & $38.1 \pm 1.2$ & $71.4 \pm 2.9 *$ & 45.8 & 79.9 & $49.6 \pm 2.1 \square^{*}$ & 69.2 & 88.4 \\
\hline $\begin{array}{l}\text { Total aqueous extract of aerial parts (100 } \\
\mathrm{mg} / \mathrm{kg})\end{array}$ & $42.6 \pm 1.7$ & $41.5 \pm 1.4$ & $82.8 \pm 3.9 *$ & 37.2 & 64.8 & $55.1 \pm 3.1$ & 65.8 & 84 \\
\hline Petroleum ether fraction $(100 \mathrm{mg} / \mathrm{kg})$ & $41.2 \pm 1.4$ & $40.1 \pm 4.7$ & $105.5 \pm 3.6^{*}$ & 20 & 34.8 & $94.7 \pm 2.6$ & 41.3 & 52.7 \\
\hline Chloroform fraction $(100 \mathrm{mg} / \mathrm{kg})$ & $39.5 \pm .12$ & $39.4 \pm 1.2$ & $114.9 \pm 4.8^{*}$ & 12.8 & 22.4 & $101.3 \pm 4.1$ & 37.2 & 47.4 \\
\hline Ethyl acetate fraction $(100 \mathrm{mg} / \mathrm{kg})$ & $39.1 \pm 0.8$ & $39.8 \pm 0.6$ & $78.4 \pm 2.3$ & 40.5 & 70.6 & $69.6 \pm 1.2$ & 56.8 & 72.5 \\
\hline Butanol fraction $(100 \mathrm{mg} / \mathrm{kg})$ & $44.1 \pm 1.3$ & $43.6 \pm 1.4$ & $89.4 \pm 3.9 *$ & 32.2 & 56.1 & $78.5 \pm 2.4$ & 51.3 & 65.5 \\
\hline
\end{tabular}

* Statistically significant from zero time at $\mathrm{p}<0.01$

-Statistically significant from $72 \mathrm{~h}$ after $\mathrm{CCl}_{4}$ at $\mathrm{p}<0.01$. 


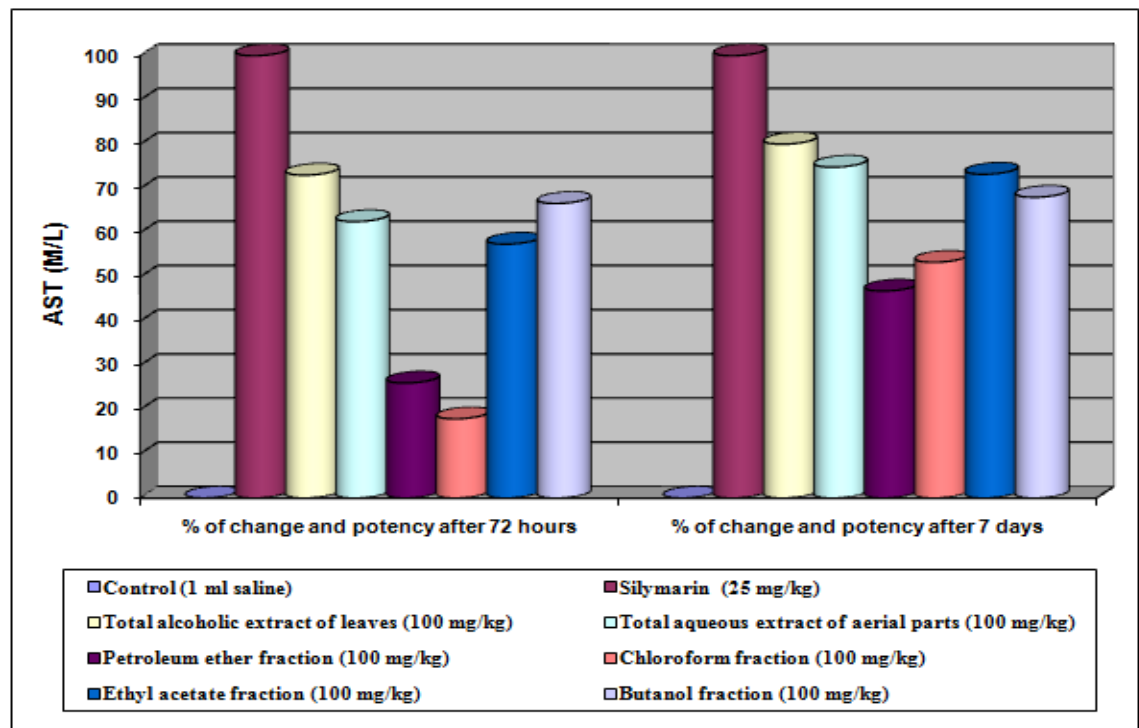

Figure (7): Hepatoprotective activity of the tested samples of Ixora finlaysoniana Wall. ex G. Don.: (Aspartate transaminase $[\mathrm{AST}(\mathrm{m} / \mathrm{L})])$

Table (7): Hepatoprotective activity of the tested samples of Ixora finlaysoniana Wall. ex G. Don.: (Alkaline phosphatase $[\mathrm{ALP}(\mathrm{m} / \mathrm{L})])$

\begin{tabular}{|c|c|c|c|c|c|c|c|c|}
\hline \multirow[t]{2}{*}{ Group } & \multicolumn{2}{|l|}{ Before } & \multicolumn{3}{|c|}{$\begin{array}{l}\% \text { of change and potency after } \\
\text { damaging liver } 72 \mathrm{hrs}\end{array}$} & \multicolumn{3}{|c|}{$\begin{array}{l}\text { \% of change and potency after } \\
\text { damaging liver } 7 \text { days }\end{array}$} \\
\hline & zero & $7 \mathrm{~d}$ & $72 \mathrm{~h}$ & $\begin{array}{l}\% \text { of } \\
\text { change }\end{array}$ & $\begin{array}{l}\% \text { of } \\
\text { potency }\end{array}$ & $7 \mathrm{~d}$ & $\begin{array}{l}\% \text { of } \\
\text { change }\end{array}$ & $\begin{array}{l}\% \text { of } \\
\text { potency }\end{array}$ \\
\hline Control (1 ml saline) & $7.1 \pm 0.1$ & $6.9 \pm 0.1$ & $48.9 \pm 1.8^{8}$ & 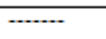 & (n)..... & $66.2 \pm 2.10^{8}$ & (n....... & (n....... \\
\hline Silymarin $(25 \mathrm{mg} / \mathrm{kg})$ & $7.2 \pm 0.1$ & $7.3 \pm 0.1$ & $19.3 \pm 0.4^{8}$ & 60.5 & 100 & $7.5 \pm 0.1^{8}$ & 88.7 & 100 \\
\hline Total alcoholic extract of leaves $(100 \mathrm{mg} / \mathrm{kg})$ & $7.1 \pm 0.1$ & $7.2 \pm 0.1$ & $27.3=0.7^{8}$ & 44.2 & 73 & $19.2 \pm 0.4 \square^{8}$ & 71 & 80 \\
\hline $\begin{array}{l}\text { Total aqueous extract of aerial parts (100 } \\
\mathrm{mg} / \mathrm{kg} \text { ) }\end{array}$ & $7.5 \pm 0.1$ & $7.4 \pm 0.1$ & $30.4=1.2^{8}$ & 37.8 & 62.5 & $22.3 \pm 0.9^{8} \square$ & 66.3 & 74.8 \\
\hline Petroleum ether fraction $(100 \mathrm{mg} / \mathrm{kg})$ & $7.2 \pm 0.1$ & $7.3 \pm 0.1$ & $41.2 \pm 1.4^{8}$ & 15.7 & 26 & $38.7 \pm 1.2^{8}$ & 41.5 & 46.8 \\
\hline Chloroform fraction $(100 \mathrm{mg} / \mathrm{kg})$ & $7.4 \pm 0.1$ & $7.5 \pm 0.1$ & $43.6 \pm 1.7^{8}$ & 10.8 & 17.9 & $34.9 \pm 1.3^{8}$ & 47.3 & 53.3 \\
\hline Ethyl acatate fraction $(100 \mathrm{mg} / \mathrm{kg})$ & $7.4 \pm 0.1$ & $7.3 \pm 0.1$ & $31.9 \pm 0.8^{8}$ & 34.8 & 57.4 & $23.2 \pm 0.7^{8} \square$ & 65 & 73.2 \\
\hline Butanol fraction $(100 \mathrm{mg} / \mathrm{kg})$ & $7.1 \pm 0.1$ & $7.2 \pm 0.1$ & $29.2 \pm 0.6^{8}$ & 40.3 & 66.6 & $26.3 \pm 0.6^{*} \square$ & 60.3 & 68 \\
\hline
\end{tabular}

* Statistically significant from zero time at $\mathrm{p}<0.01$

-Statistically significant from $72 \mathrm{~h}$ after $\mathrm{CCl}_{4}$ at $\mathrm{p}<0.01$.

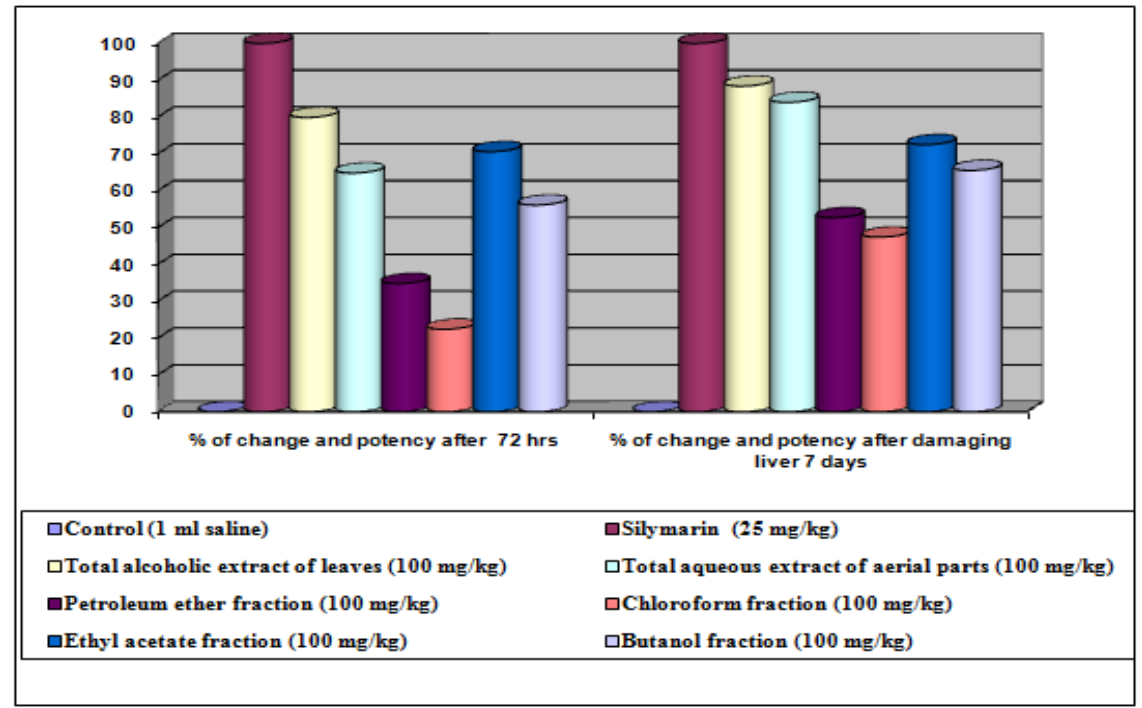

Figure (8): Hepatoprotective activity of the tested samples of Ixora finlaysoniana Wall. ex G. Don.: (Alkaline phosphatase $[\mathrm{ALP}(\mathrm{m} / \mathrm{L})])$ 
Table(8): Hepatoprotective activity of the tested samples of Ixora finlaysoniana Wall. ex G. Don.: (Alanine transaminase $[\operatorname{ALT}(\mathrm{m} / \mathrm{L})])$

\begin{tabular}{|c|c|c|c|c|c|c|c|c|}
\hline \multirow[t]{2}{*}{ Group } & \multicolumn{2}{|l|}{ Before } & \multicolumn{3}{|c|}{$\begin{array}{l}\% \text { of change and potency after } \\
\text { damaging liver } 72 \text { hrs }\end{array}$} & \multicolumn{3}{|c|}{$\begin{array}{l}\% \text { of change and potency after } \\
\text { damaging liver } 7 \text { days }\end{array}$} \\
\hline & zero & $7 d$ & $72 \mathrm{~h}$ & $\begin{array}{l}\% \text { of } \\
\text { change }\end{array}$ & $\begin{array}{l}\% \text { of } \\
\text { potency }\end{array}$ & $7 d$ & $\begin{array}{l}\% \text { of } \\
\text { change }\end{array}$ & $\begin{array}{l}\% \text { of } \\
\text { potency }\end{array}$ \\
\hline Control (1 ml saline) & $36.8 \pm 1.2$ & $37.1 \pm 1.4$ & $141.3 \pm 4.2^{*}$ & -...- & -..-- & $156.9 \pm 4.3 * *$ & $+\cdots-$ & -..-- \\
\hline Silymarin $(25 \mathrm{mg} / \mathrm{kg})$ & $39.1 \pm 1.3$ & $38.4 \pm 1.2$ & $61.9 \pm 2.4^{*}$ & 56.2 & 100.0 & $38.2 \pm 1.1 \cdot *$ & 75.7 & 100.0 \\
\hline $\begin{array}{l}\text { Total alcoholic extract of } \\
\text { leaves }(100 \mathrm{mg} / \mathrm{kg})\end{array}$ & $40.5 \pm 1.7$ & $39.2 \pm 1.3$ & $51.6 \pm 3.5^{*}$ & 63.5 & 113.0 & $46.8 \pm 3.1^{*} \cdot$ & 70.2 & 92.8 \\
\hline $\begin{array}{l}\text { Total aqueous extract of aerial } \\
\text { parts }(100 \mathrm{mg} / \mathrm{kg})\end{array}$ & $37.8 \pm 1.4$ & $37.5 \pm 1.1$ & $78.3 \pm 4.2^{*}$ & 44.6 & 79.3 & $53.5 \pm 3.9 * \bullet$ & 65.9 & 87.1 \\
\hline $\begin{array}{l}\text { Petroleum ether fraction (100 } \\
\mathrm{mg} / \mathrm{kg})\end{array}$ & $38.5 \pm 1.3$ & $38.6 \pm 1.2$ & $118.7 \pm 5.1$ & 16.0 & 28.5 & $101.3 \pm 4.8$ & 35.4 & 46.8 \\
\hline $\begin{array}{l}\text { Chloroform fraction }(100 \\
\mathrm{mg} / \mathrm{kg})\end{array}$ & $41.9 \pm 1.7$ & $41.7 \pm 1.3$ & $124.3 \pm 5.28$ & 12.0 & 21.4 & $109.6 \pm 4.7$ & 30.1 & 39.8 \\
\hline $\begin{array}{l}\text { Ethyl acetate fraction (100 } \\
\mathrm{mg} / \mathrm{kg})\end{array}$ & $33.9 \pm 1.1$ & $31.5 \pm 0.9$ & $83.6 \pm 2.7$ & 40.8 & 72.7 & $61.3 \pm 1.6$ & 60.9 & 80.5 \\
\hline Butanol fraction $(100 \mathrm{mg} / \mathrm{kg})$ & $42.5 \pm 1.6$ & $42.3 \pm 1.7$ & $81.1 \pm 4.9^{*}$ & 42.6 & 75.8 & $69.7 \pm 3.4^{*}$ & 55.6 & 73.5 \\
\hline
\end{tabular}

* Statistically significant from zero time at $\mathrm{p}<0.01$

-Statistically significant from $72 \mathrm{~h}$ after $\mathrm{CCl}_{4}$ at $\mathrm{p}<0.01$.

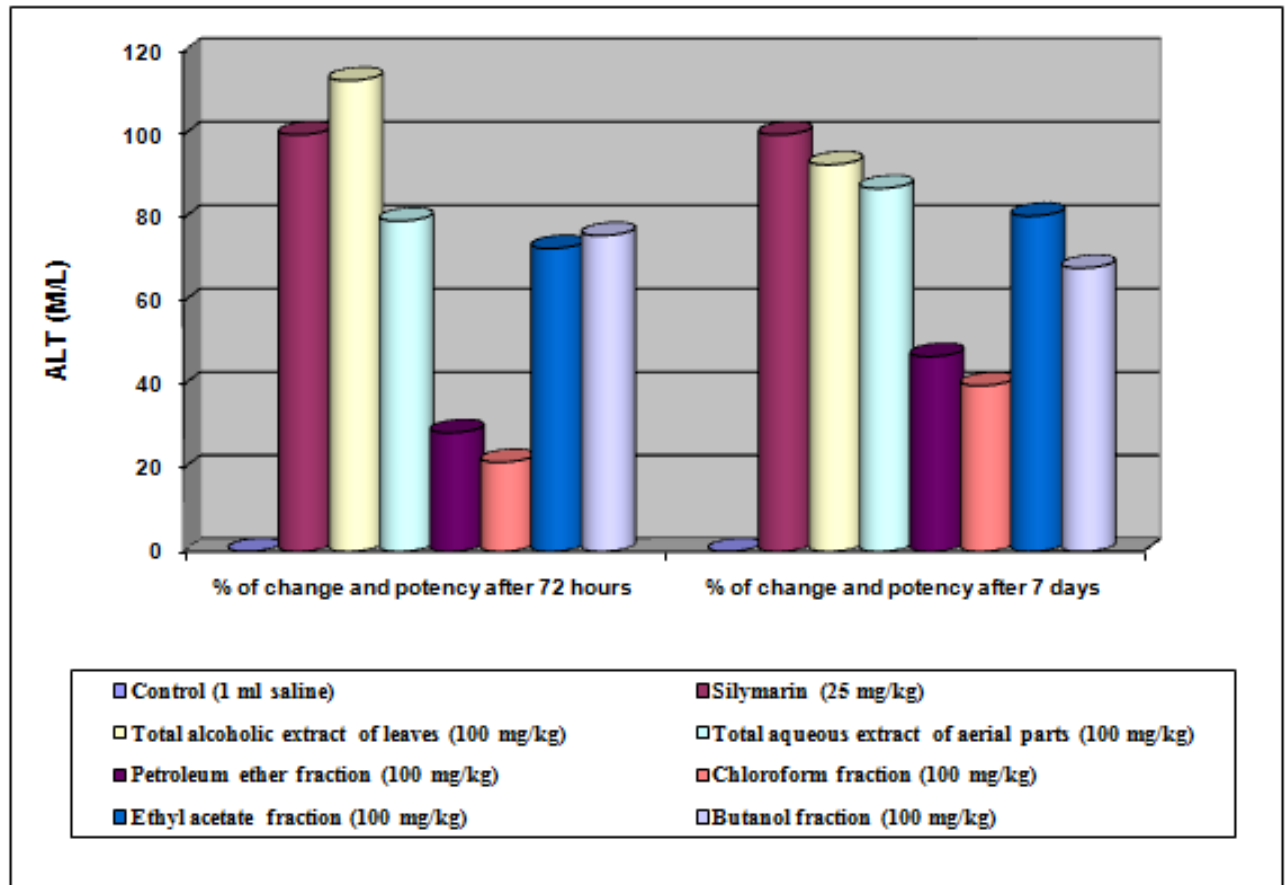

Figure (9): Hepatoprotective activity of the tested samples of Ixora finlaysoniana Wall. ex G. Don.: (Alanine transaminase $[\operatorname{ALT}(\mathrm{m} / \mathrm{L})])$ 